Article

\title{
"We Started Building Green IT Back in the 1970s": Making Sense of Sustainable ICT through Organizational History
}

\author{
Per Fors * (i) and Thomas Taro Lennerfors \\ Department of Engineering Sciences, Uppsala University, 75121 Uppsala, Sweden; \\ thomas.lennerfors@angstrom.uu.se \\ * Correspondence: per.fors@angstrom.uu.se; Tel.: +46-762819922
}

Received: 31 May 2018; Accepted: 26 July 2018; Published: 30 July 2018

\begin{abstract}
Traditionally, research related to Sustainable Information and Communication Technology (Sustainable ICT) has focused on the technological aspects, but there is an emerging stream of research, which looks at Sustainable ICT from the viewpoint of the social sciences. In this paper, we build on and contribute to this research by emphasizing the role of history in the shaping of Sustainable ICT. Rather than seeing the importance of history as pure technological determinism or path dependency, we draw on the historical turn in organizational studies to highlight the idea that history is malleable. This implies that organizational actors can reshape their past from the present, thus creating new conditions for the future. To highlight the importance of this theoretical conceptualization of history, we present a case study of the Nordic ICT company Tieto, where the heat recovery system of the Älvsjö data center (finished in 1978) was reconceptualized as "green" following the Green Information Technology (Green IT) trend in 2007. This way of theorizing organizational history could be used more widely within research into Sustainable ICT in order to understand why Sustainable ICT has become what it is, which also implies that we can re-interpret this history to shape the future of Sustainable ICT.
\end{abstract}

Keywords: organizational history; identity; Sustainable ICT; Green IT; sustainable data center

\section{Introduction}

Information and Communication Technology (ICT) has become a cornerstone of modern society and an integral part of everyday life. In tandem with the surge in discourse on global warming and sustainable development in the late 1900s, research on the relationship between ICT and environmental aspects has intensified, often under umbrella terms such as Green Information Technology (IT) and Sustainable ICT. Traditionally, research related to ICT and environmental aspects-and sustainable data centers in particular-has been quantitative, focusing mainly on the technological aspects of ICT, using methods such as Life Cycle Assessment (LCA). However, as stated by among others Hilty et al. [1] and Fuchs [2], environmental problems are social problems and will never be solved by efficient technology as such. This insight has recently resulted in theories and research methods from the social sciences having gained a foothold within fields related to Sustainable ICT [3]. Practice theoretical perspectives [4-7], post-colonial and Marxist perspectives [8,9] and sensemaking, translation theory and Actor-Network Theory (ANT) [10-12] are examples of such theories and methods.

In this paper, we aim to draw on and contribute to this tradition of thought by highlighting the role of organizational history in making sense of both technological trajectories and discourses related to sustainability in ICT companies. In earlier research, we described how the history of energy saving as well as the various climate change mitigation policies operational in the Japanese context 
fundamentally shaped the translation of Green IT into Japan [12]. Similar historical processes have been investigated in other publications in a Swedish context $[8,11]$. However, the historical processes described in this research are often undertheorized, which might imply that the perspective adopted is too linear and deterministic. This has resulted in downplaying the role of history to mere past events that have implication for the future. We see this tendency not only in our own research, briefly mentioned above, but also as a general tendency in qualitative publications within fields related to ICT and environmental aspects.

To resolve this issue, we have drawn on the theorization of history present within the "historical turn" in organization studies, i.e., organization research with a special interest in historical processes. The reason for this is not only that this stream of research is aware of and interested in the theoretical foundations of historical studies, but also that the case we have researched in this paper concerns historical processes related to sustainability in an ICT service company. Scholars arguing for a historical turn claim that organization researchers have traditionally failed to properly understand the role and impact of historical processes for the unfolding of organizational events such as the development of organizational identity and the adoption of certain practices and technologies. Their main message is that history is "malleable" [13] (p. 622) and open to interpretation rather than given and immutable [14-18], and that organizational actors often use dispersed historical memory cues to create a sense of meaning and coherence in organizational narratives $[19,20]$.

In starting this dialogue between Sustainable ICT and the historical turn within organization studies, we argue that Sustainable ICT practices and/or technologies are not only adopted because they are superior, i.e., more sustainable or profitable, to other practices and/or technologies. Rather, this process is also greatly affected by how organizational actors make sense of and interpret past historical events. Making sense of the past, however, often results in new conditions for the future.

To provide an empirical grounding for our theoretical approach, we have chosen to do case study research about how the Nordic ICT company Tieto is making sense of Sustainable ICT and their identity through various past events. Tieto have been held up as role models, especially within the Nordic countries, not least since they were named the world's leading ICT company by the non-profit organization CDP (previously called the Carbon Disclosure Project) in 2011 [21]. In contrast to most other ICT companies, Tieto is actively promoting the sustainability of heat recovery systems, i.e., systems that enable the reuse of data center exhaust air for heating applications. Rather than arguably more conventional approaches such as free cooling, aiming for a low Power Usage Effectiveness (PUE) ratio, Tieto argues that heat recovery is superior to any other sustainability measure for data center cooling [22]. According to Tieto, their emphasis on heat recovery stems from their 1970s data center in Älvsjö, Stockholm, which was equipped with a heat recovery system. In 2011, when they inaugurated their top-of-the-line heat recovering data center in Espoo, they explained that the center was "a testament to our long-term efforts to develop sustainable ... solutions" [23] (p. 33). This seems to be an obvious case of how the past influences the present. However, in this paper, using the organizational history literature as our theoretical inspiration, we aim to unpack the Tieto case to show that much more was at stake than just pure historical determinism. Another important contribution of our research is thus an empirical analysis of the Sustainable ICT history of Tieto.

The paper is structured as follows. In Section 2 we present our theoretical view of history based on the historical turn in organization studies. In Section 3 we present the case study, followed by Section 4 where we analyze the case study using our theoretical framework. The fifth and final part concludes the paper and sketches the implications of this theoretical approach for the study of Sustainable ICT.

\section{Theorizing Organizational History}

As has been argued in the introduction, we aim to contribute to the theoretical understanding of history as a factor in research into Sustainable ICT by drawing on organizational studies. In this part, we describe how organizational researchers have viewed history in the past and the new developments in the field that are occurring at present. We claim that the field of organization studies is more 
historically aware than most fields interested in ICT and sustainability, and hold that we can learn much from the way history is theorized within organization studies, as well as learning from the plethora of case studies produced within the field. In this part, we propose a way in which the role of history could be theorized within research into Sustainable ICT in organizations.

Researchers studying organizations have traditionally had an unreflective view of organizational history, seeing it merely as given, immutable facts about the past [20] with implications for the competitiveness of a particular organization [24-27]. One consequence of this perspective is that it ignores that organizational actors have the ability to shape, interpret and renegotiate their history. This, among other things, has urged researchers to call for a historical turn within organization studies, a new research stream which more fully explores the role of history in organizations. Researchers adhering to this perspective see the past as conditioned by the present from which it is viewed, and thus as malleable and open to interpretation [13-15]. They see organizational actors as inclined to reinterpret past events so that they seem consistent with how they want the organization to be perceived in the present and the future, especially events that otherwise would seem inconsistent or ambiguous [13,28].

According to the leading researchers within the historical turn, Hatch and Schultz, there are two related but distinct streams within such research [17]. One stream focuses mainly on how managers deliberately use or manipulate certain aspects of their organization's history in order to serve the interests of the organization $[18,20,29,30]$. The second stream focuses more on how actors mobilize historical memory cues such as artifacts, texts or discourses, in order to make sense of the organizational identity $[16,17,31,32]$. The first stream is more focused on the role of managers in constructing the history of the organization while the second stream is more interested in the historical sensemaking of a variety of organizational actors. Below we summarize the aspects of each stream which we found to be most significant for the analysis of our case study.

Researchers contributing to the first stream tend to start from the assumption that managers appropriate certain elements from the organization's collective memory $[18,20]$ and create unique interpretations of them in line with how they want their organization to be perceived. Especially meaningful past events are often imbued with new meaning and presented as parts of a coherent narrative that signifies the values that the managers want the organization to be associated with [19]. This links the organization, both in the present and in the past, to broader social phenomena, historical events, institutions and discourses (such as sustainable development). Moreover, they can also choose to deliberately "forget" certain aspects of their past [33]. Anteby and Molnár, for instance, shows how a French aeronautics firm through "structural omission" cut contradictory elements from their past in order for their history to seem more coherent [18]. This kind of "selective storytelling" can be used to legitimize present and future strategic initiatives [17].

The second stream of research often draws on sensemaking theory $[14,34]$ in order to describe how organizational actors collaboratively shape organizational identity by referring to or mobilizing "heritage symbols, traditional cultural practices, or memory forms" [17] (p. 659). In an empirical illustration of this perspective, Hatch and Schultz drew attention to the micro-processes related to organizational historicizing when Carlsberg revived an old company motto-Semper Ardens ("always burning")-that had lain dormant for almost a decade, in order to indicate authenticity for a line of limited edition craft beer [17]. In another important paper in this stream, Schultz and Hernes focus on the different memory forms (oral, textual and material) used by the company LEGO to evoke their past in ongoing and future initiatives [16]. They drew particular attention to the founder's motto Det bedste er ikke for godt ("Only the best is good enough"), materialized in the form of a hand-carved sign placed above the CEO's desk, to remind him of the significance of LEGO's long history. They argue that while oral and textual memory cues are vital in identity construction, material artifacts provide direct manifestations of what "something looked like or felt like ... creating an immediacy of experience while remaining open to differing interpretations" [16] (p. 6). In contrast to oral memory, the authenticity of the material artifact itself can never be questioned. However, the meaning of the artifact, i.e., how and why it was previously used, is open to interpretation [16]. This combination of 
openness and closedness makes material artifacts particularly effective in reinforcing organizational values. They can be used to both embed and to express identity claims. They can be imbued with meaning and values and used to express these values to internal and external actors as an integral part of identity creation [35].

According to these two streams of research, history is seen as used instrumentally by organizational actors to reshape the past with implications for the present and future, or as a resource pool for organizational actors to use to explore new ways of perceiving the organization's identity. In the second stream, there are more explicit discussions about various forms of memory cues, and researchers belonging to this stream have argued that material memory cues, i.e., the memory of a certain material artifact, can be a particularly effective basis for identity construction. For our study, this insight is crucial since we will argue that the Älvsjö data center is exactly such an artifact. Both streams have made important contributions to the research, but it is what unites them that is most important: the perception of organizational history as malleable and fluid, and open to interpretation. Although both research streams have argued that history is malleable, one should not forget that the particular resources which present organizational members can draw on to recreate the organization's history are indeed determined by the past. For example, that the motto Semper Ardens had existed in the past was a prerequisite for there being a revival of it. Therefore, we construct a theoretical understanding of history as both to some extent determining the present as well as being determined by it. Meanwhile, efforts aimed at creating history can have long-lasting and unexpected effects on an organization's future opportunities and development, making these efforts both problematic and complex, with unexpected outcomes.

This theoretical understanding of historical processes in organizations will be made manifest in the case study of Tieto, showing their efforts to create an identity intrinsically linked to sustainable values.

\section{Empirical Case Study: Kommundata, Tieto and the Sustainable Data Center in Älvsjö}

In this section, we present the case of how Tieto is struggling to make sense of Sustainable ICT in the 2000s. This history could have started around 2000, when Tieto felt the need to address environmental issues. Or, it could have started in 2007, when the global trend of Green IT swept over the company. It was indeed after 2007 when the heat recycling data center in Älvsjö, built by the ICT company Kommundata AB in 1978 and later owned by Tieto, became a central artifact used by Tieto as a base for its Sustainable ICT efforts. Given our theoretical review, we know that history is malleable. To truly understand what the Älvsjö data center was before 2007, we will start from the beginning. In order to provide an understanding of the organizational, spatial and temporal context in which this data center was built and why, a short historical summary of the birth of Kommundata is presented in Section 3.1, followed by an in-depth description of the data center and how it was constructed in the discourse at the time (Section 3.2). Section 3.3 provides an account of the acquisition of what remained of Kommundata AB by TietoEnator in 1999, and in Section 3.4 we describe how memories of the Älvsjö data center were evoked by Tieto when positioning themselves as part of various sustainability trends in the 2000s.

The empirical case study research design [36], is based on interviews, archival studies, and observations. Interviews and meetings with key people within the Green IT and Sustainable ICT movement in Sweden were carried out between 2011 and 2018. At Tieto, we interviewed the persons responsible in the past and present for the development and operation of Tieto's data centers, as well as Tieto's sustainability manager. Our research team also interviewed representatives from a number of other organizations concerning historical perspectives on the development of data centers. As part of monitoring the Green IT and Sustainable ICT trends in Sweden, we have attended and observed several keynote presentations by the sustainability manager about Sustainability at Tieto, always featuring the Älvsjö data center. To corroborate the interview data, an archival study was carried out in the summer of 2017, which included the staff magazine Datten 1976-1993, available at the National Library 
of Sweden, as well as publicly available material such as TietoEnator AB Annual Reports 2000-2009, Tieto AB Annual Reports 2008-2017, and Tieto AB Corporate Responsibility Reports 2006-2017.

\subsection{Kommundata $A B$ and Its History}

Until the 1960s, Swedish municipalities had relied on mechanical and electromechanical hand-operated calculators for all their calculations. In the 1960s, they started to show interest in replacing these calculators with more efficient, but expensive, computers. In 1964 Stadsförbundet, the public interest association for Sweden's municipalities, decided to start building a centralized data center for Swedish municipalities on Hornsgatan in Stockholm [37]. The interest was significant, as most municipalities did not have their own data centers. Stadsförbundet established an organization around the data center, Kommun-Data, and procured several mainframes; among them Remington's Univac 1106 and an old Univac 1104 [37]. In the early days, they were mainly used for operations related to child allowances; calculations of electricity, gas, water and rent charges; accounting and salaries [38]. In 1968, Kommun-Data was privatized. The digitalization of the public sector in Sweden was rapid, not least within the public sphere, and Kommun-Data AB (later Kommundata) was positioned as one of the few companies that could support this development. Thus, they expanded to Västberga Allé in 1971, and established a backup facility in Skellefteå in 1974 in order to reach out to Northern Sweden's municipalities. In 1975 and 1976, Kommun-Data was established at two new locations, first in Gävle and then in Lund. In 1977, they acquired the ICT company NorrData, and started to provide applications and services also to the banking sector. By this acquisition, Kommundata had successfully eliminated most of its competition, and in 1978 they supplied Electronic Data Processing (EDP) services to 267 of Sweden's 278 municipalities. While 7 municipalities had their own data centers, only four used other external suppliers [38]. Furthermore, they employed 485 people in eight different offices; three of them located in Stockholm. The business was growing and the need for data processing and storage was increasing rapidly. There was a need for a modern, centralized, data center to handle future challenges.

\subsection{The New Facility in Älvsjö, Stockholm}

Given this background, it was decided that a new data center should be built. In this section, we present the data center as it was described discursively in contemporary sources. As the reader will notice, many of the aspects of the data center described do not relate to environmental issues.

In this relocation project named Projekt Sjöbotten, Kommundata's Stockholm departments would move to Älvsjö, south of Stockholm [39]. Hans Schultz from Kommundata was assigned project manager and the state-owned engineering company KommunKonsult was responsible for the construction. The new premises were to consist of four main buildings: a warehouse, a two-story production facility, a seven-story office building, and a building that would host the canteen and recreation facilities [40]. Here, one large and two smaller gymnasiums were planned (only one was built), as well as a swimming pool with adjacent saunas and showers, a workshop, and darkrooms for photography $[39,41]$. The production facility, i.e., the data center itself, was dimensioned to accommodate four large mainframe systems [42], and would extend over two stories. This would substantially reduce the noise level which employees in the older facilities had complained about, thus greatly improving working conditions. The data center would accommodate the Saab D20 and the Varian previously located at Sveavägen, as well as the Eclipse and the Univac 1106 [43]. In addition, a brand-new single-processor Saab Univac 1100/81 was decided on, which would be upgraded to a $1100 / 82$ by adding another processor [44]. Connected to the data center there would also be a printer room, dimensioned for 15 printers [39].

The security of the data center was discursively constructed as "exceptional" and emphasized in both internal and external media. In 1983, the facility was called "one of Sweden's most secure data centers" and was referred to as "the bunker in Älvsjö" on the Studio G program on Swedish Television (SVT) [44,45]. The data center had thick concrete walls and security glass "strong enough 
to withstand machinegun fire" [46] (p. 40). The few openable windows were used only in case of fire, and could only be opened by the fire department. Rotary flywheels and batteries were used as an Uninterruptible Power Supply (UPS), and after extensive improvements in 1984, when two new converters were installed; all the mainframes had UPS [47]. The Älvsjö facility was also the first data center in the world with high voltage cables coated with a flame-retardant material [39].

Less emphasized in contemporary documents and the media was the installed heat recovery system [48], which would become important later in Tieto's framing of the data center and their company as historically "green". The only brief mention of this system that we have been able to find is the following: "The heat that is generated by the mainframes will not only be transported away from the facility, but be used to heat the other buildings" [41] (p. 1). In our interviews with the main architect of the system, he explained that cooling units with an extra condenser connected to a dumping condenser were used. In this way, the heat generated by the ICT equipment could be reused for heating the two-story production facility in which the data center was located, in addition to the seven-story office building and the warehouse. During winter, at least 80 percent of the required heating could be provided by excess heat from the ICT equipment. While the technology itself was not very complicated, the system required the whole block to be constructed with the heat recovery system in mind. He further explained that the heat recovery system was installed for purely economic reasons. During the mid-1970s, when the oil price increased by about 400 percent, Sweden was one of the most oil-dependent countries in Europe [49]: "The oil crises were fresh in their minds ... it was never about 'Green $\mathrm{IT}^{\prime \prime}$ '. The heat recovery system was later complemented with a free cooling system that could be used during the winters, but this system was unsophisticated and not often used.

The success of the heat recovery system at the Älvsjö facility inspired Kommundata to implement similar systems in some of their future facilities. The waste heat from the new data center in Lund was used to heat their offices, and in Skellefteå waste heat was used to heat a nearby hotel. The heat that could not be used by the hotel was transported directly to the district heating system. In 1989, $3500 \mathrm{MWh}$ of waste heat was recovered in Skellefteå [50]. In Jönköping, the cooling system used $9{ }^{\circ} \mathrm{C}$ water which was taken from a borehole near the lake Vättern. In their facility in Borlänge they used an ice thermal storage system. While this solution saved money, an indirect positive effect was a balancing of the power grid load. However, at the time none of these systems were seen as related to environmental issues.

\subsection{From Kommundata to Tieto}

Kommundata continued to grow, not least after new CEO Göte Jonsson was appointed in 1982. Almost every municipality in Sweden was using their services, and they had successfully expanded into the healthcare and banking sectors. In 1992, however, the Swedish economy suffered a recession and the ICT market underwent rapid changes. Municipalities and county councils started to set up their own, internal ICT departments with standardized software solutions. Furthermore, the public sector was becoming increasingly commercialized, leading to increased competition [51]. Contemporary reports showed that Kommundata's relations with public sector organizations were crumbling and that their systems and applications were not competitive enough. Kommunförbundet (formerly Stadsförbundet) who owned Kommundata realized that they no longer needed their own ICT company in order to procure cost-effective ICT services, and eventually sold it (renamed Dialog in a desperate attempt to target the private sphere) to Celsius Industries (later Enator). At least 900 Kommundata employees were let go in the process. In 1999, Enator merged with the Finnish ICT company Tieto, formed in Espoo in 1968, and formed TietoEnator. The merger with the equivalent-sized Enator marked a tipping point for Tieto, which became one of the largest IT companies in the Nordic countries. In 2008, they changed their name back to Tieto. Now there were only a few remnants left of Kommundata in Tieto [38]. But shortly after the merger with Tieto, there was increasing pressure from the market to respond to environmental concerns. To this, we now turn. 


\subsection{Tieto's Sustainability Efforts: From Reaction to Affirmation}

In the early 2000s, the ICT sector saw the need to respond to environmental concerns. Since its launch in 1996, the environmental management system ISO 14001 had already gained ground in other sectors by the late 1990s, and in the early 2000s this new environmental pressure was discussed internally at TietoEnator. The Swedish national rail company had recently started rebranding its goods transport division to "Green Cargo", and the former architect of the heat recovery system at Älvsjö suggested that TietoEnator should start branding itself "Green Data". However, the interest in such rebranding was low and TietoEnator preferred to follow the industry standard by implementing an environmental management system. In 2002, TietoEnator received their first ISO 14001 certificate. The following year, they started their Corporate Responsibility (CR) activities. However, they were clearly lagging behind the industry average in the environmental dimension [52]. They concluded in their annual report that in order to become more environmentally sustainable, they had to put more emphasis on environmental reporting. In 2005, their CR framework was launched, which established new policies and revised existing ones.

In 2007, Green IT, which took a broader and more proactive approach to the environmental impact of ICT, was announced [53]. This broader focus meant that there was no longer a direct connection between environmental management systems such as ISO 14001 and ICT sustainability. Green IT meant that the ICT industry should now focus not only on reducing the environmental impact of ICT itself (Greening of ICT) but also on exploiting the potential of using ICT for sustainability purposes (Greening by ICT). As it is commonly held that sustainable or "smart" ICT solutions can enable a 20 percent reduction in global greenhouse gas emissions by 2030-while Greening of ICT would only contribute an around 2 percent reduction [54] - Greening by ICT quickly became the favored discourse within the industry [8]. It is thus not remarkable that this was the year when the Älvsjö data center was reborn in the discourse as an environmentally sustainable data center. The broadening of the sustainability discourse surrounding ICT most likely created the backdrop for the history of the Älvsjö data center to be mobilized. Heat recovery does indeed reduce environmental impact on other parts of the community, and can therefore be seen as Greening by ICT.

Given this broadened scope, TietoEnator now had something that they could fit into the discourse about Green IT. Before that, they only had environmental management systems, just like every other ICT company. TietoEnator started promoting a more aggressive discourse about sustainability from this point. They concluded that "Green IT [is] becoming increasingly important" [55] (p. 29) and started to develop a new Green IT policy which was released the same year. That year they also released their first Corporate Responsibility Report. The report was very brief, not least since they had not yet developed any Key Performance Indicators (KPIs) for environmental performance. However, their Green IT targets for the next 5 years were ambitious. They aimed not only to start measuring the environmental impact of their data centers, but also to lower the energy consumption of their data centers by $35-50$ percent [56].

After 2007, the Älvsjö data center was not only diligently mentioned in their annual and Corporate Responsibility reports as a good example of Green IT, but used to mark the starting point for Tieto's sustainability initiatives (see Environmental Roadmap, [57]). Their Sustainability Manager also used the data center as a case of Green IT in various speeches and seminars. 2009 was an important year for Tieto's sustainability efforts, not least because they developed and introduced their Sustainability Intelligence Service, used to collect, store and calculate their CR performance, and decided to start reporting on their CR performance annually. Their goal was to become the global leader in Green IT. This was described as a natural step for Tieto, since they had been "environmentally aware since the 1970s" [57] (p. 3). A prime example is this paragraph in their CR report, under "History of responsibility": 
We have been committed to environmental work for several decades. In the late 1970s, we began to reuse surplus energy from a data centre in Sweden to heat a nearby office building. About 80 percent of the energy needed to heat the office was captured from large chillers in the data centre and recycled, saving more than three million kilowatt-hours, which is equivalent to the amount of energy needed to heat about 200 family-sized houses in Sweden for a year. (p. 13)

During the years following 2009, their sustainability efforts were further intensified. Apart from the virtualization and consolidation of servers, heat recycling remained a hot topic, because of the re-birth of the Älvsjö data center in discourse as a champion of sustainability. Given this renewed focus on heat recovery, they started to build the "Tieto Cave" in 2009, a data center in an old Swedish military base in Tullinge outside Stockholm, which was going to recycle excess heat into the district heating system. So far, it has not been used to heat the surrounding area, partly because the development of the area has been slower than initially expected. In 2011, their brand-new data center in Espoo, featuring a heat recovery system, which provided heat to the district heating system equal to the need of 1500 residential houses, was opened. It is estimated that 78 percent of the total energy consumption of the center is being reused for heating purposes [58]. The center was ranked as one of the most efficient data centers worldwide by the CDP [22], and Tieto was ranked as the most sustainable ICT service company worldwide, and the most sustainable company in the Nordic region [22].

Considering that the Finnish side of TietoEnator had no interest whatsoever in the heat recovery systems prior to the mid-2000s, according to a Swedish data center facility officer at Tieto, this might seem remarkable. The reinvention of TietoEnator as a company whose sustainability efforts are centered around heat recovery probably led to an acceptance of the technology. While the PUE ratio of the Espoo data center is far better than for most other data centers, they consistently emphasize the superiority of heat recovery systems over other solutions for sustainability purposes. After 2011, the Älvsjö data center seems to have lost its status as a sustainability champion for Tieto. Still, it lives on as a touchstone for their sustainability efforts.

\section{Analysis: The Role of Älvsjö in the Creation of Tieto's Sustainability Profile}

In the previous section, based on the case study research, we described how the history of Tieto's sustainability efforts was intertwined with the construction of Kommundata's data center in Älvsjö in the late 1970s (the main outline is shown in Figure 1). Although the construction of our empirical case in the previous section is already influenced by our theoretical approach, in this section we delineate more explicitly some analytical themes related to the historical turn in organizational studies.

International environmental issues have been slowly emerging since the 1960s, with important texts such as the Silent Spring and the Limits to Growth study. However, the environment as an important issue truly kicked off in the late 1980s with the Brundtland report, which is still considered to be a seminal document. Companies all over the world had to start thinking about not only producing competitive products and services, but also creating social and environmental value. The majority of ICT companies joined this movement quite late compared to many other industries. In the case of Tieto, they were faced with pressure to engage in environmental sustainability in the early 2000s. This pressure was mostly concerned with instituting an environmental management system, ISO 14001 . However, they were struggling with how to make sense of environmental sustainability. The architect of the Älvsjö heat recovery system, as mentioned in the empirical narrative, proposed introducing the concept of Green Data, but within the context of environmental certification this really did not make sense. Greenness for ICT companies at the time was about environmental certification, not so much about marketing or branding. Some employees were aware of the existence of the heat recovery system in Älvsjö, but there was no natural way of using this resource within the overarching discourses about sustainability in the ICT industry at the time.

We argue that the Green IT trend, started in 2007, was an external trigger which re-interpreted what sustainability in the ICT industry could be. Rather than seeing it as a question of introducing 
certification, which could hardly boost competitiveness, Green IT aimed to put emphasis also on the positive environmental impact of ICT. The Älvsjö data center was seen in this context as an artifact that created a positive impact on society by providing "free" heating. Thus, the Älvsjö data center could be imbued with new meaning, as a fundamental part of the sustainability efforts of TietoEnator. A champion had been created in the present, out of something that had lain dormant for 30 years. The architect of the heat recovery system said: "No one was particularly excited about the heat recovery system, it's not like we had study visits to the data center because of it at the time". Rather, the facility was praised for its security levels and good working environment among other things.

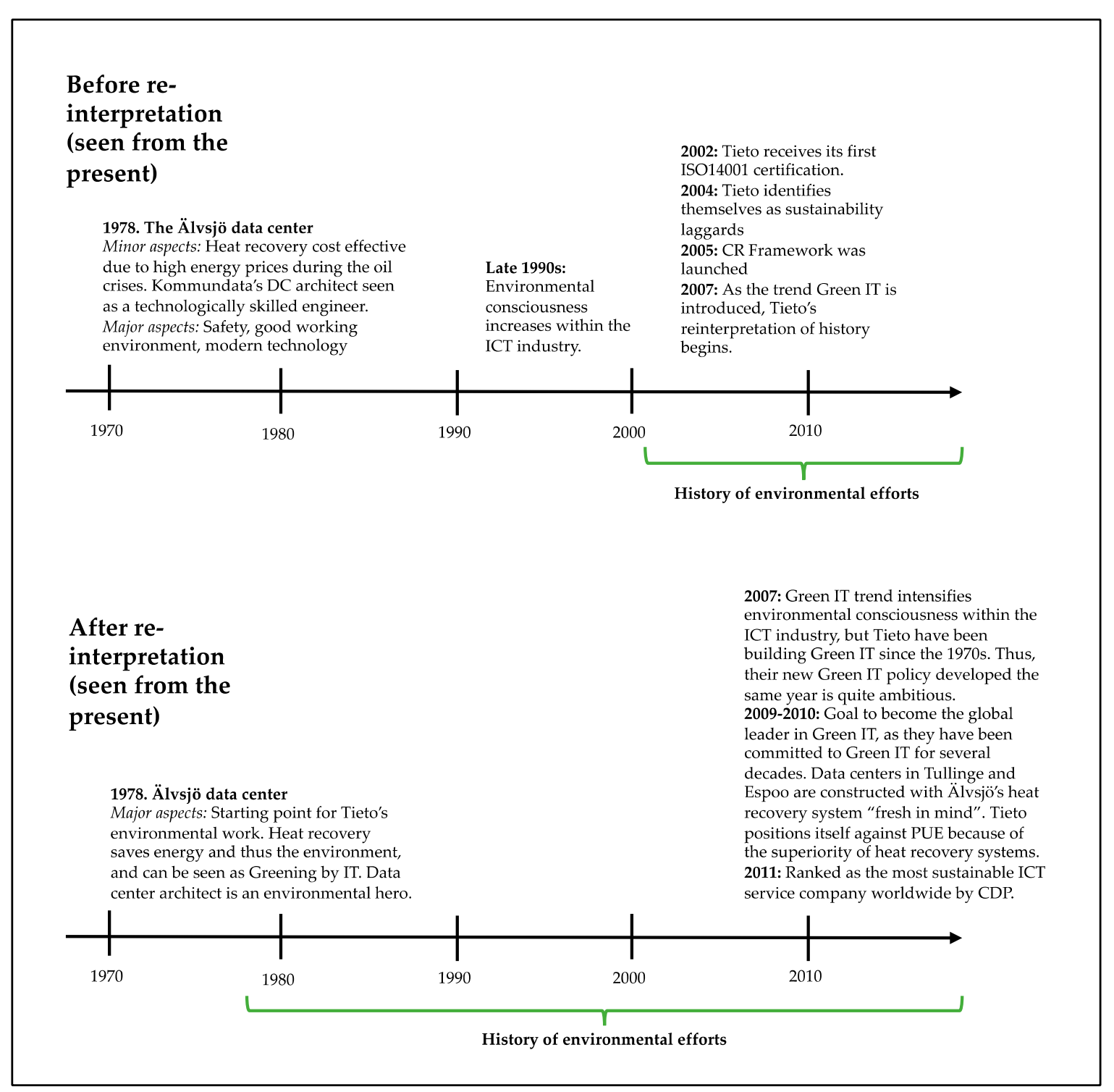

Figure 1. The creation of coherence and meaning intrinsically linked to sustainability values at Tieto.

The heat recovery system was not only seen as a champion in the present, but it also had the benefit that it was old. This was used in the sense making of environmental sustainability at Tieto. We can read in their Corporate Responsibility Report from 2010 that they "begun already in 1978 to reuse energy from servers to heat our own office space in Älvsjö" [59] (p. 43). Given that the heat recovery system was a material artifact, the authenticity of it could hardly be questioned. Schultz and Hernes argue that while oral and textual memory cues are vital in identity construction, material artifacts provide direct manifestations of how "something looked like or felt like ... creating an immediacy of 
experience while remaining open to differing interpretations" [16] (p. 6). We argue that a change in the global discourse about sustainability in the ICT industry contributed to the possibility to re-imagine the material and thus very "real" heat recovery system as Green IT and later Sustainable ICT.

In various speeches in the early 2010s, Tieto's sustainability manager connected Tieto's sustainability efforts not only with the heat recovery system of the Älvsjö data center but also with the person behind it, the architect. He was described as an environmental hero and one of the first to work with environmental issues within the Swedish ICT sector. He himself claims that he was neither, but by connecting the technology to a spokesperson for it, Tieto used its past not just to argue that there was a heat recovery system already in 1978, but that this heat recovery system was built with environmental values in mind. These constructed memories from the past have been used to create cohesion and meaning [19], creating a clear line from the 1970s to the present not only of environmental consciousness at Tieto but of a particular form of technology. However, as we have already described, the oil crisis in the early 1970s was the only motivation at the time for reducing the use of energy for heating purposes. This, however, was downplayed when the Älvsjö data center was mobilized for sustainability purposes. As organizational researchers argue, companies such as Tieto can chose to deliberately omit aspects from their narratives which expose ideological or political purposes [18,33], such as a purely for-profit orientation. This is not to say that the economic focus of the Älvsjö heat recovery system is a secret. Rather, "saving energy to save money" has been re-interpreted as "saving energy". Tieto thus produced and drew on their socially constructed past to show that they have always been environmentally conscious, and could justify future energy-saving and sustainability initiatives [17]. Rather than seeing this as a case of deliberately green-washing their past, we see it as a sensemaking process where certain memory cues are evoked in order to orientate themselves towards these trends and develop a more sustainable identity or profile. This allows them to collectively understand and communicate their world-leading position in 2011 not as a response to sustainability trends, but as a natural continuation of their sustainability efforts and thus as a natural part of their identity (see Figure 1).

However, we have stated that history is not only open to creative re-interpretation but that it also influences and shapes the present and the future. The re-emergence of the Älvsjö data center as a sustainability champion had implications for how Tieto's future data centers were constructed. While other companies-such as Facebook and IBM-mainly rely on free cooling rather than heat recovery, Tieto emphasizes that heat recovery is the most important measure for energy efficiency and to reduce the environmental impact of data centers: "We are convinced that the smartest way of optimizing energy efficiency is by re-using excess heat from data center servers" [21] (p. 21). The architect of the heat recovery system in Älvsjö argues that "economically speaking, free cooling is better [but] from a sustainability perspective, heat recycling is superior". This led to two different but related consequences for future initiatives. First of all, Tieto started building data centers inspired by the technology used in the Älvsjö data center, although they had not used this technology for 30 years. They have told us that they had the Älvsjö data center "fresh in mind" when starting the construction of the Tieto Cave in 2009. Secondly, while having one of the most efficient data centers even by conventional standards, its strong focus on heat recovery led Tieto to openly criticize the focus on PUE ratios within the industry, and to work on alternative and more accurate metrics: "[PUE] does not take into account recycling and re-use of excess heat, which is perhaps the best opportunity to enhance energy efficiency in data centers" [58] (p. 38). Many of Tieto's data centers can utilize free cooling, but they are actively trying to deviate from and criticize these more conventional solutions.

What are the consequences of these historically formed sustainability discourses for the future? Given our theoretical framework, it is likely that these created discourses about sustainability will continue to affect Tieto. This does not necessarily mean that Tieto have to keep implementing heat recovery systems in all their future facilities, but if they suddenly shift their discourse to promoting PUE, then it is likely that they will lose some credibility. To keep being credible, they probably need to stick to heat recovery technology for some time. However, given our framework, there are 
creative ways of doing so. Usually the data about how much heat is recovered does not need to be disclosed, which means that Tieto does not need to use heat recovery even though they have these systems installed. Such a creative re-interpretation is already working at the Tieto Cave in Tullinge. It is emphasized that this data center can recover heat, even though it does not do so in the present. This pushes heat recovery, for this particular data center, into the future, as a promised but yet not realized actuality.

\section{Conclusions}

In this paper, we set out to argue that Sustainable ICT is far more than just about technology. Social aspects related to technology are important, and in this paper, we have argued that historical processes need to be considered to understand what Sustainable ICT "is" for different organizations and in different contexts. Drawing on the historical turn within organization studies, we have argued that history both determines the present as well as is determined by it. Thus, by re-imagining past events for whatever reason in the present, we also create a lasting impact on the future. We argued that such an understanding of history is rare within fields related to Sustainable ICT, but could prove very relevant for studies trying to understand how and why certain sustainable ICT practices and/or technologies are chosen and implemented. Our first contribution is thus to introduce a more sophisticated view of history than that which is often used within the fields of sustainability and ICT.

By researching the case of Tieto, we have shown how the heat recovery system of the Älvsjö data center was re-imagined as "green" in the wake of the trend Green IT. This was a re-interpretation of the purely economic motives when the system was installed which became the foundation for Tieto's transition from sustainability laggard to sustainability leader. However, this new sustainability discourse also has an impact on the future-since Tieto is now identified as a sustainability leader with a strong base in heat recovery - which implies that they need to stick to the technology and discourse in practice in order to remain credible. However, according to our framework this can also be done in creative ways. Our second contribution is thus to provide an empirical account of how a leader in Sustainable ICT has been using its history creatively for this purpose. By providing this account, we hope to have shown that this theoretical approach is applicable to the field of Sustainable ICT. But there are more implications which go beyond individual corporations such as Tieto.

By acknowledging the importance of history as well as highlighting the dual processes of it as something that impacts us while we have an impact of it, we hold that we can get a clearer view of Sustainable ICT practices and technologies, with many implications for further research. This perspective allows us to start asking fundamental questions such as: How and why did various corporate actors promote certain ways of achieving Sustainable ICT? Why is it that some actors are more interested in free cooling-what are the historical processes behind this-and how are sustainability discourses produced as a complex interplay between the present and the past?

While this paper has mainly been concerned with one specific technology (i.e., heat recovery systems) within one specific organization (i.e., Tieto), we can see how other more specific issues within Sustainable ICT can be approached with similar research methods. One such example could be the development of green technologies within the field of communication [60-62]. Since the world during the last decades has become increasingly networked and interconnected, it is also important to follow the environmental impacts of this development from a historical perspective. It is likely that historical processes shape technological choices rather than technical/rational factors only, but that history is also re-created from the vantage point of the networked and interconnected present.

We can also start asking similar questions at a macro level: Why was the trend Green IT formed as it was? What were the historical processes behind it? We have previously followed the adoption of Green IT in Sweden [11] and in Japan [12], but without focusing on historical processes. We indicate in another paper that the historical development of Green IT as a trend shows that the interest in sustainability in the IT industry was linked to the broadening from "Green" to "Sustainable" which 
included more economic perspectives [8]. But how was this shift possible? Who were the actors driving it, and how did they re-interpret history in order to create the future?

Author Contributions: P.F. carried out the literature review (see Section 2) and the archival studies that form the basis for the empirical narrative (see Section 3), and wrote the first draft versions of the paper, which were then edited by both authors. T.T.L. had the main responsibility for the analysis of the empirical narrative (see Section 4 ) and the conclusions (see Section 5) together with P.F. They have both contributed equally to the data collection through interviews, meetings and seminars carried out between 2011 and 2018. The paper has been proofread and edited by a professional translator and editor.

Funding: This research received no external funding.

Acknowledgments: The authors would like to thank the editors and the reviewers for their useful and insightful comments and suggestions.

Conflicts of Interest: The authors declare no conflict of interest.

\section{References and Notes}

1. Hilty, L.; Lohmann, W.; Huang, E. Sustainability and ICT-An overview of the field. Politeia 2011, 27, 13-28.

2. Fuchs, C. The implications of new information and communication technologies for sustainability. Environ. Dev. Sustain. 2008, 10, 291-309. [CrossRef]

3. Fuchs, C. Internet and Society: Social Theory in the Information Age; Routledge: Abingdon, UK, 2007.

4. Börjesson Rivera, M. Practice Makes Perfect?: Sustainable Practices with ICT and Daily Travel. Ph.D. Thesis, KTH Royal Institute of Technology, Stockholm, Sweden, 2015.

5. Börjesson Rivera, M.; Eriksson, E.; Wangel, J. ICT Practices in Smart Sustainable Cities: In the Intersection of Technological Solutions and Practices of Everyday Life. In Proceedings of the EnviroInfo and ICT for Sustainability 2015, Copenhagen, Denmark, 7-9 September 2015; pp. 317-324.

6. Gram-Hanssen, K. Standby consumption in households analyzed with a practice theory approach. J. Ind. Ecol. 2010, 14, 150-165. [CrossRef]

7. Røpke, I.; Christensen, T.H. Energy impacts of ICT-Insights from an everyday life perspective. Telemat. Inform. 2012, 29, 348-361.

8. Lennerfors, T.T.; Fors, P.; van Rooijen, J. ICT and environmental sustainability in a changing society: The view of ecological World Systems Theory. Inf. Technol. People 2015, 28, 758-774. [CrossRef]

9. Fuchs, C.; Mosco, V. Introduction: Marx is back-the importance of Marxist theory and research for critical communication studies today. TripleC Commun. Capital. Crit. Open Access J. Glob. Sustain. Inf. Soc. 2012, 10, 127-140. [CrossRef]

10. De Zoysa, M.R.; Letch, N. ICT4D Project Sustainability: An ANT-based Analysis. In Proceedings of the Americas Conference on Information Systems AMCIS2013, Chicago, IL, USA, 15-17 August 2013.

11. Fors, P.; Lennerfors, T.T. Translating Green IT: The case of the Swedish Green IT Audit. In Proceedings of the First International Conference on Information and Communication Technologies for Sustainability, Zürich, Switzerland, 14-16 February 2013; pp. 208-216.

12. Majima, T.; Udagawa, M.; Yotsumoto, M.; Lennerfors, T.T. Green IT Did Not Take Place: The Translation of Environmentally Friendly IT in Japan. J. Inf. Manag. 2017, 37, 81-96.

13. Gioia, D.A.; Corley, K.G.; Fabbri, T. Revising the Past (While Thinking in the Future Perfect Tense). J. Organ. Chang. Manag. 2002, 15, 622-634. [CrossRef]

14. Weick, K.E. Cognitive processes in organizations. Res. Org. Behav. 1979, 1, 41-74.

15. Mead, G.H. Mind, Self and Society; University of Chicago Press: Chicago, IL, USA, 1934.

16. Schultz, M.; Hernes, T. A Temporal Perspective on Organizational Identity. Organ. Sci. 2013, $24,1-21$. [CrossRef]

17. Hatch, M.J.; Schultz, M. Toward a theory of using history authentically: Historicizing in the Carlsberg Group. Adm. Sci. Q. 2017, 62, 657-697.

18. Anteby, M.; Molnar, V. Collective memory meets organizational identity: Remembering to forget in a firm's rhetorical history. Acad. Manag. J. 2012, 55, 515-540. [CrossRef]

19. Czarniawska, B. Narrating the Organization: Dramas of Institutional Identity; University of Chicago Press: Chicago, IL, USA, 1997. 
20. Foster, W.M.; Suddaby, R.; Minkus, A.; Wiebe, E. History as social memory assets: The example of Tim Hortons. Manag. Organ. Hist. 2011, 6, 101-120. [CrossRef]

21. Carbon Disclosure Project 2011. Carbon Disclosure Leadership Index. Available online: https://www.cdp. net/en (accessed on 24 July 2018).

22. Tieto Annual Report 2016. Available online: https://ar2016.tieto.com/media/download-centre/en/annualreport-full-report.pdf (accessed on 31 March 2018).

23. Tieto Corporate Responsibility Report 2011. Available online: https:/ /www.tieto.com/sites/default/files/ migrated/documents /Tieto_CR_report_2011.pdf (accessed on 31 March 2018).

24. Hannan, M.T.; Freeman, J. Organizational Ecology; Harvard University Press: Cambridge, MA, USA, 1989.

25. Miller, D.; Friesen, P.H. Momentum and revolution in organizational adaptation. Acad. Manag. J. 1980, 23, 591-614.

26. Teece, D.J. Economies of scope and the scope of the enterprise. J. Econ. Behav. Org. 1980, 1, $223-247$. [CrossRef]

27. Barney, J.B. Organizational culture: Can it be a source of sustained competitive advantage? Acad. Manag. Rev. 1986, 11, 656-665. [CrossRef]

28. Levitt, B.; March, J.G. Organizational learning. Annu. Rev. Sociol. 1988, 14, 319-338. [CrossRef]

29. Suddaby, R. Challenges for institutional theory. J. Manag. Inq. 2010, 19, 14-20. [CrossRef]

30. Brunninge, $\mathrm{O}$. Using history in organizations: How managers make purposeful reference to history in strategy processes. J. Organ. Chang. Manag. 2009, 22, 8-26. [CrossRef]

31. Kroezen, J.J.; Heugens, P.P.M.A.R. Organizational identity formation: Processes of identity imprinting and enactment in the Dutch microbrewing landscape. Constr. Identity Organ. 2012, 3, 89-127.

32. Ravasi, D.; Schultz, M. Responding to organizational identity threats: Exploring the role of organizational culture. Acad. Manag. J. 2006, 49, 433-458. [CrossRef]

33. Rowlinson, M.; Hassard, J. The invention of corporate culture: A history of the histories of Cadbury. Hum. Relat. 1993, 46, 299-326. [CrossRef]

34. Gioia, D.A.; Chittipeddi, K. Sensemaking and sensegiving in strategic change initiation. Strat. Manag. J. 1991, 12, 433-448. [CrossRef]

35. Schultz, M.; Hatch, M.J.; Ciccolella, F. Brand life in symbols and artifacts: The LEGO company. In Artifacts and Organizations: Beyond Mere Symbolism; Rafaeli, A., Pratt, M.G., Eds.; Psychology Press: Hove, UK, 2006; pp. 141-160.

36. Yin, R.K. Case Study Research—Design and Methods; Sage publications: Thousand Oaks, CA, USA, 2017.

37. As stated in the main text, there are physical copies available at the archive of the National Library of Sweden in Stockholm. The references have different formats because they did not have volume/issue numbers before the mid 1980s. Datten 1982-02-24, Kommundata: Stockholm, Sweden.

38. Knutsson, N. Från räknesnurra till Dataplatta: 60 år med Kommunal IT 1954-2014; Institutet för Informationsteknologi: Stockholm, Sweden, 2015.

39. As stated in the main text, there are physical copies available at the archive of the National Library of Sweden in Stockholm. The references have different formats because they did not have volume/issue numbers before the mid 1980s. Datten 1976-10-26, Kommundata: Stockholm, Sweden.

40. As stated in the main text, there are physical copies available at the archive of the National Library of Sweden in Stockholm. The references have different formats because they did not have volume/issue numbers before the mid 1980s. Datten 1976-11-30, Kommundata: Stockholm, Sweden.

41. As stated in the main text, there are physical copies available at the archive of the National Library of Sweden in Stockholm. The references have different formats because they did not have volume/issue numbers before the mid 1980s. Datten 1976-05-25, Kommundata: Stockholm, Sweden.

42. As stated in the main text, there are physical copies available at the archive of the National Library of Sweden in Stockholm. The references have different formats because they did not have volume/issue numbers before the mid 1980s. Datten 1976-09-20, Kommundata: Stockholm, Sweden.

43. As stated in the main text, there are physical copies available at the archive of the National Library of Sweden in Stockholm. The references have different formats because they did not have volume/issue numbers before the mid 1980s. Datten 1978-03-08, Kommundata: Stockholm, Sweden. 
44. As stated in the main text, there are physical copies available at the archive of the National Library of Sweden in Stockholm. The references have different formats because they did not have volume/issue numbers before the mid 1980s. Datten 1985, 4, Kommundata: Stockholm, Sweden.

45. As stated in the main text, there are physical copies available at the archive of the National Library of Sweden in Stockholm. The references have different formats because they did not have volume/issue numbers before the mid 1980s. Studio, G. Swedish Television show at Sweden's Television. Aired 1983-05-03.

46. As stated in the main text, there are physical copies available at the archive of the National Library of Sweden in Stockholm. The references have different formats because they did not have volume/issue numbers before the mid 1980s. Datten 1978-05-23, Kommundata: Stockholm, Sweden.

47. As stated in the main text, there are physical copies available at the archive of the National Library of Sweden in Stockholm. The references have different formats because they did not have volume/issue numbers before the mid 1980s. Datten 1984, 5, Kommundata: Stockholm, Sweden.

48. Lundmark, J. Utvecklingen av Energieffektiv Teknologi I Svenska Datorcenter. Master's Thesis, Uppsala University, Uppsala, Sweden, 2013.

49. Johansson, P. A Silent. Revolution: The Swed. Transit. Towards Heat Pumps, 1970-2015. Ph.D. Thesis, KTH Royal Institute of Technology, Stockholm, Sweden, 2017.

50. Datten 1989, 1, Kommundata: Stockholm, Sweden.

51. Springdal, K. Privatisation of the IT Sector in Sweden. Ph.D Thesis, Institute of Economic Research, Lund University, Lund, Sweden, 2001.

52. Tieto Annual Report 2004. Available online: https://web.lib.aalto.fi/fi/old/yrityspalvelin/pdf/2004/ Etietoenator2004.pdf (accessed on 31 March 2018).

53. Mingay, S. Green IT: The New Industry Shock Wave. Gartner RAS Research Note. Available online: https:/ / goo.gl/6RH68J (accessed on 27 July 2018).

54. Global e-Sustainability Initiative (GeSI). \#SMARTer 2030: ICT Solutions for 21st Century Challenges. 2015. Available online: http:/ / smarter2030.gesi.org/downloads/Full_report2.pdf (accessed on 31 March 2018).

55. Tieto Annual Report 2007. Available online: https://www.tieto.se/sites/default/files/migrated/ documents/TE_ar_en_1-64_2.pdf (accessed on 31 March 2018).

56. Tieto Corporate Responsibility Report 2007. Available online: https://www.tieto.com/sites/default/files/ migrated/documents /CR_Review_2007.pdf (accessed on 31 March 2018).

57. Tieto Corporate Responsibility Report 2009. Available online: https://www.tieto.com/sites/default/files/ migrated/documents/Tieto_CR_final.pdf (accessed on 31 March 2018).

58. Tieto Corporate Responsibility Report 2012. Available online: https://www.tieto.com/sites/default/files/ atoms/files/tieto_corporate_responsibility_2012.pdf (accessed on 31 March 2018).

59. Tieto Corporate Responsibility Report 2010. Available online: https://www.tieto.com/sites/default/files / migrated/documents/TIETO_CR-report-2010.pdf (accessed on 31 March 2018).

60. Gandotra, P.; Jha, R.K. Next generation cellular networks and green communication. In Proceedings of the 10th International Conference on Communication Systems \& Networks, Bangalore, India, 4-6 January 2018.

61. Tsiropoulou, E.E.; Kapoukakis, A.; Papavassiliou, S. Energy-efficient subcarrier allocation in SC-FDMA wireless networks based on multilateral model of bargaining. In Proceedings of the IFIP Networking Conference, New York, NY, USA, 22-24 May 2013.

62. Tsiropoulou, E.E.; Vamvakas, P.; Papavassiliou, S. Joint customized price and power control for energy-efficient multi-service wireless networks via S-modular theory. IEEE Trans. Green Commun. Netw. 2017, 1, 17-28. [CrossRef]

(C) 2018 by the authors. Licensee MDPI, Basel, Switzerland. This article is an open access article distributed under the terms and conditions of the Creative Commons Attribution (CC BY) license (http:/ / creativecommons.org/licenses/by/4.0/). 